\title{
Giant Fibroadenomas in Young Women
}

\author{
Genç Kadınlarda Dev Fibroadenomlar
}

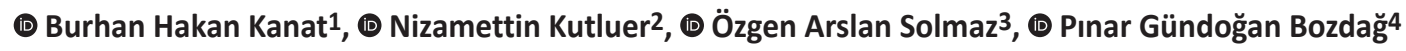 \\ ${ }^{1}$ Turgut Özal University, School of Medicine, Department of General Surgery, Malatya, Turkey \\ 2University of Health Sciences Turkey, Elazığ Fethi Sekin State Hospital, Clinic of General Surgery, Elazığ, Turkey \\ 3 University of Health Sciences Turkey, Elazığ Fethi Sekin State Hospital, Clinic of Patology, Elazığ, Turkey \\ 4University of Health Sciences Turkey, Elazığ Fethi Sekin State Hospital, Clinic of Radiology, Elazığ, Turkey
}

\section{Abstract}

Objectives: In this study, we consider a fibroadenoma with a size $>5 \mathrm{~cm}$ as a giant fibroadenoma (GFA). This definition is not universally accepted but has been used in several studies. We retrospectively presented fibroadenoma cases that were treated in our clinic, together with a review of the current literature.

Materials and Methods: The GFA cases that were surgically treated in our clinic between January 2016 and December 2019 were retrospectively reviewed. The data were collected from patient files, discharge reports, surgical notes, pathology reports, patient follow-up forms, and digital records. Patients whose data were not fully available were excluded from the study. The patients were analyzed in terms of age, duration of symptom, macroscopically size of the mass and location.

Results: Eight patients were analyzed. The mean age of the patients was $31.5 \pm 5.8$ (23-41) years. The mean time of diagnosis before the operation was $36.75 \pm 14.49(18-60)$ months. The lesion was in the left breast for five patients $(62.5 \%)$ and in the right breast for three patients (37.5\%). The mean size of fibroadenomas was $52.5 \pm 2(50-56) \mathrm{mm}$.

Conclusion: There is not a consensus in the ideal treatment protocol of GFAs. A careful physical examination and radiological examination are sufficient for diagnosis, but a biopsy will be beneficial in the context of a GFA. We think that excision should be done in the treatment of GFAs.

Key Words: Giant Fibroadenoma, Treatment, Biopsy

\section{Özet}

Amaç: Bu çalışmada biz $5 \mathrm{~cm}$ ve üzeri boyutu olan fibroadenomları dev fibroadenom (DFA) olarak değerlendirdik. Her ne kadar bu tanımlama genel olarak kabul edilmese de birçok çalışmada bu şekilde tarif edilmiştir. Bu yazıda kliniğimizde tedavi ettiğimiz DFA tanılı hastaları literatür eşliğinde retrospektif olarak sunmayı amaçladık.

Gereç ve Yöntem: Kliniğimizde Ocak 2014 - Aralık 2019 tarihleri arasında DFA nedeni ile cerrahi tedavi uygulanan hastalar retrospektif olarak incelendi. Çalışma verileri hasta dosyalarından, epikrizlerden, ameliyat notlarından, patoloji raporlarından, hasta takip formlarından ve bilgisayar kayıtlarından elde edildi. Verilerine tam olarak ulaşılamayan hastalar çalışma dışına alındı. Hastalar; yaş, şikayet süresi, makroskopik olarak kitle boyutu ve yerleşim yeri açısından analiz edildi.

Bulgular: Altı yıllık süreç içerisinde kliniğimizde DFA nedeni ile opere edilen dokuz hastadan bir tanesinin verilerine tam olarak ulaşılamayınca çalışma sekiz hasta üzerinden yapıldı. Hastaların yaş ortalaması 31,5 55,8 yıl olup yaş aralığı 23-41 yıl arasında değişmekteydi. Hastaların fibroadenomlarının farkındalık süreleri ortalama $36,75 \pm 14,49$ ay $(18-60)$ idi. Beş hastada $(\% 62,5)$ lezyon sol memede iken üç $(\% 37,5)$ hastada sağ

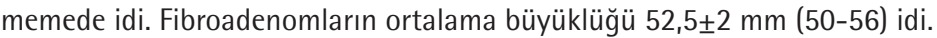

Sonuç: DFA'ların tedavisi konusunda henüz bir fikir birliği oluşmamıştır. Tanı için dikkatli bir fizik muayene ve radyolojik tetkikler yeterli olmakla birlikte DFA'larda biyopsi faydalıdır. Biz DFA'ların tedavisinde eksizyon yapılması gerektiğini düşünüyoruz.

Anahtar Kelimeler: Dev Fibroadenom, Tedavi, Biyopsi

Address for Correspondence/Yazışma Adresi: Assoc. Dr. Burhan Hakan Kanat, MD,

Turgut Özal University, School of Medicine, Department of General Surgery, Malatya, Turkey

Phone: +90 4228461255 E-mail: burhankanat@hotmail.com ORCID: orcid.org/0000-0003-1168-0833

Received/Geliş: 12.01.2020 Accepted/Kabul: 07.06.2020

๑Copyright 2020 Ankara University Faculty of Medicine

Journal of Ankara University Faculty of Medicine is published by Galenos Publishing House.

All content are under CC BY-NC-ND license. 


\section{Introduction}

Fibroadenomas are solid, benign breast lesions that are most commonly observed in women between the ages of 20 and 40; however, they may develop in women of all ages. A fibroadenoma will present as a mobile mass in the breast tissue (1). Fibroadenoma cases are common in clinics; however, there is not a standard algorithm that is used for monitoring fibroadenoma patients or for the decision of the course of treatment. The poorly defined excision criteria are particularly an issue. Forty years ago, excision was the standard treatment option for all types of fibroadenomas. Further research suggested that biopsy and ultrasonography (USG) follow-ups could also be a safe option $(2,3)$. Nonetheless, there is no universal consensus.

There are several aspects regarding fibroadenomas that are debated by authors, including their classification, risk of malignancy, possible treatment approaches. In this study, we consider a fibroadenoma with a size $>5 \mathrm{~cm}$ as a giant fibroadenoma (GFA). This definition is not universally accepted but has been used in several studies (4). Most GFAs are surgically excised as a result of persisting symptoms, such as asymmetry, pain, compression in surrounding tissues or changes in the skin.

We retrospectively present fibroadenoma cases that were treated in our clinic, together with a review of the current literature.

\section{Materials and Methods}

The GFA cases that were surgically treated in our clinic between January 2016 and December 2019 were retrospectively reviewed. Ethics committee approval was received from University of Health Sciences, Elazığ Fethi Sekin State Hospital (no: 13281952-702.99, date: 01.09.2020). However, consent was obtained from the hospital management for processing the data. Written and verbal informed consent was obtained from patients who participated in this study. Before surgery, patients signed an informed consent form for the surgical procedure and subsequent treatment, and the necessary permission was obtained to use their data in our analyses.

The data were collected from patient files, discharge reports, surgical notes, pathology reports, patient follow-up forms, and digital records. The exclusion criteria were: (a) incomplete/ insufficient data. The data were analyzed using several parameters: age, the time between initial diagnosis and surgical intervention, size, and location of GFA.

All patients underwent physical examination and USG prior to the operation. In the cases where USG results were insufficient, patients were further examined with mammography or magnetic resonance imaging (MRI). The tru-cut biopsy was used to preoperatively obtain tissue samples. After confirmed diagnosis, the patients were operated under general anesthesia, and the masses were removed. Drainage was not required for any of our patients (Figure 1 and 2).

\section{Statistical Analysis}

Statistical analysis of the study was performed using SPSS 20 (SPSS for Windows, Inc., Chicago, IL, USA). Data were presented

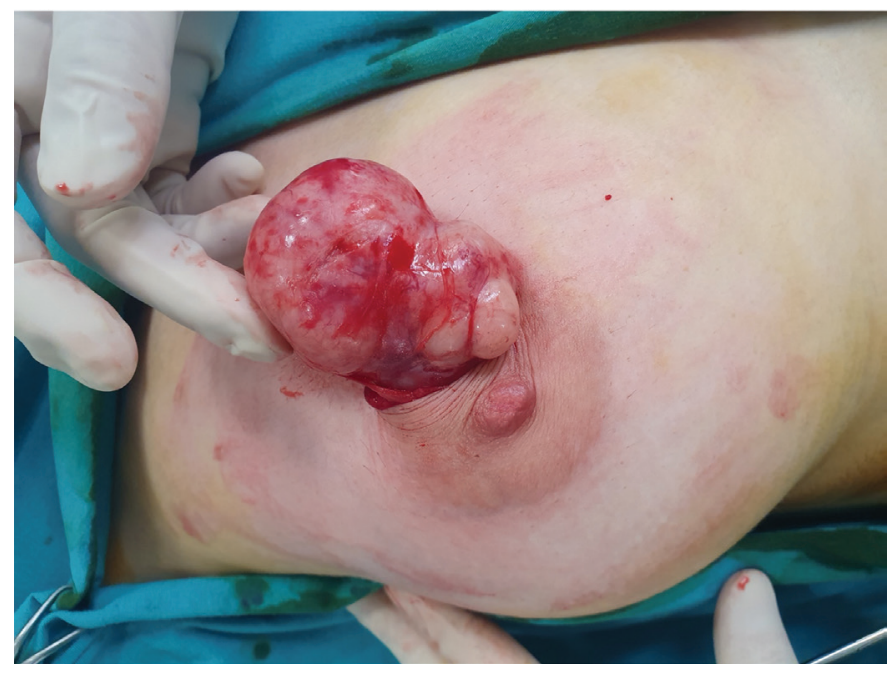

Figure 1: Image of a giant fibroadenoma removed from the incision made from the areola line

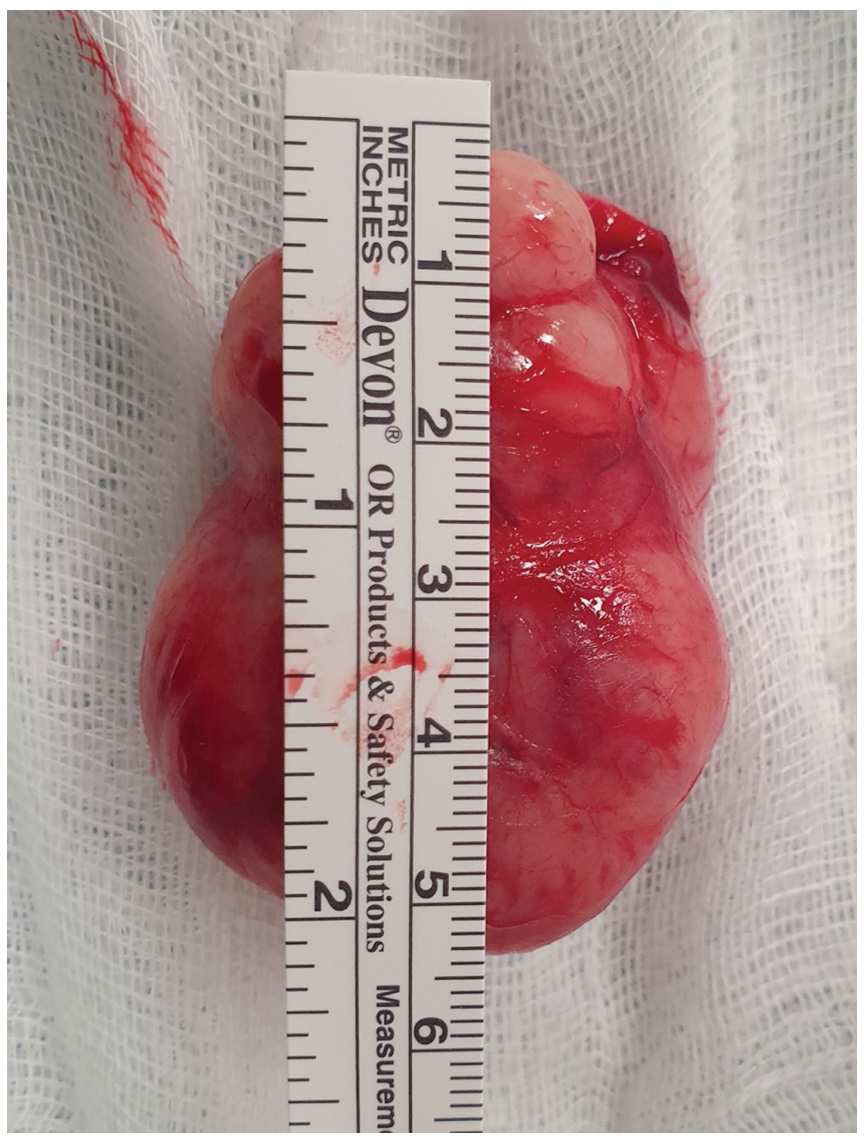

Figure 2: Measurement of the size of a giant fibroadenoma 
as percentage and arithmetic mean \pm standard deviation (minimum-maximum).

\section{Results}

A total of 9 GFA patients' records were accessed for the study. Of the patients, one patient was excluded from the study due to incomplete data. The data from the remaining eight patients were analyzed. The mean age of the patients was $31.5 \pm 5.8(23-41)$ years. The mean time of diagnosis before the operation was $36.75 \pm 14.49$ (18-60) months. The lesion was in the left breast for five patients (62.5\%) and in the right breast for three patients (37.5\%). The mean size of fibroadenomas was $52.5 \pm 2(50-56) \mathrm{mm}$.

One patient that was over 40 years old was additionally examined with mammography, whereas one patient underwent MRI for the differential diagnosis of a cyst in the contralateral breast, which was detected during USG. None of the patients had a family history of breast cancer. One patient had previously undergone fibroadenoma excision that was localized in the contralateral breast. None of the other patients had a history of breast surgery.

Eight patients were discharged without any postoperative problems. Bleeding occurred in one patient. Compression was made, followed by dressing. Tru-cut biopsy results were compatible with fibroadenoma in all our patients. This result corresponded with the postoperative pathology result.

\section{Discussion}

Fibroadenomas are the most common cause of breast masses in adolescents and young adults. Rarely, they grow large enough to require the need for intervention. The etiology is not completely understood; however, estrogen is a suspected factor in pathogenesis. A careful physical examination and radiological examination are sufficient for diagnosis, but a biopsy will be beneficial in the context of a GFA (4-6), as it will help determine the surgical approach. Authors have expressed difficulties in distinguishing fibroadenomas from phyllodes tumors solely through radiological examinations, such as USG and mammography. This distinction is critical as the treatment of fibroadenomas will be different from that of phyllodes tumors, especially if malignant (7-9). Therefore, we are in favor of large-core needle biopsy to confirm the GFA diagnosis before surgical intervention.

The histopathological structure of a GFA consists of epithelial and stromal components. The specific characteristic of these components will determine the differential diagnosis. The epithelial component will consist of the simple cuboidal epithelium, with possible proliferative changes: metaplasia, ductal hyperplasia, atypical ductal hyperplasia, or carcinoma in situ. The histopathologic structure of the stromal component is highly specific, with a collagenous and spindle-celled composition (Figure 3). It should be noted that it may be difficult to differentiate fibroadenomas with hypercellular stroma from phyllodes tumor through Tru-Cut biopsies (10).

USG is widely used to evaluate palpable breast lesions in women less than 40 years of age. It is important to note that mammography is not efficient for younger women, and thus, it has limited use in the diagnosis of fibroadenomas. However, if applicable to the patient, mammography may prove handy in defining the additional infiltrative lesions. Thus, mammography should be recommended for patients with uncertain diagnoses, and patients of suitable age, even if the diagnosis is already confirmed. If the patient with an uncertain diagnosis is not old enough for mammography, MRI can be used to confirm the diagnosis (1). For our subjects; one underwent mammography due to their age, whereas another patient underwent MRI for the differential diagnosis of a cyst in the contralateral breast,

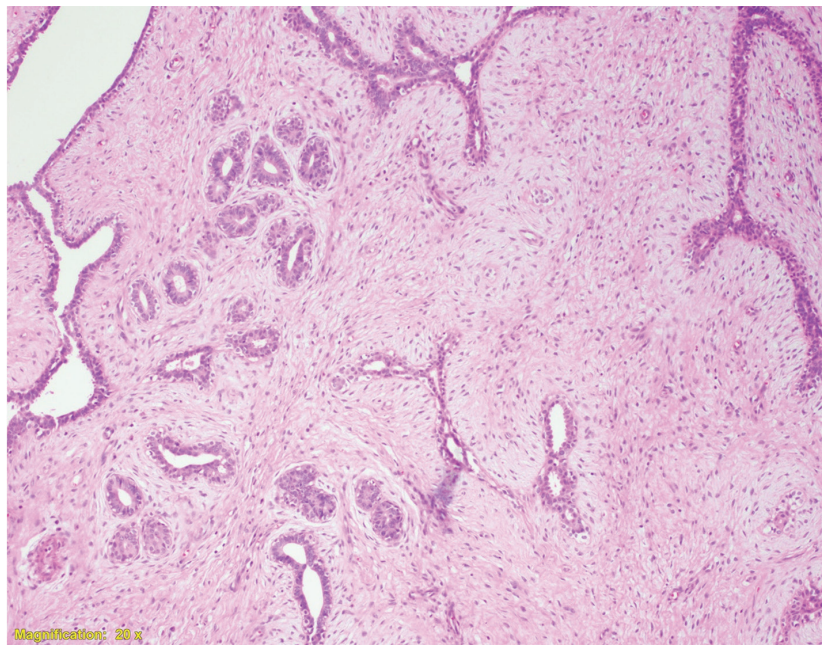

Figure 3: The histopathologic structure of the stromal component is highly specific, with a collagenous and spindle-celled composition

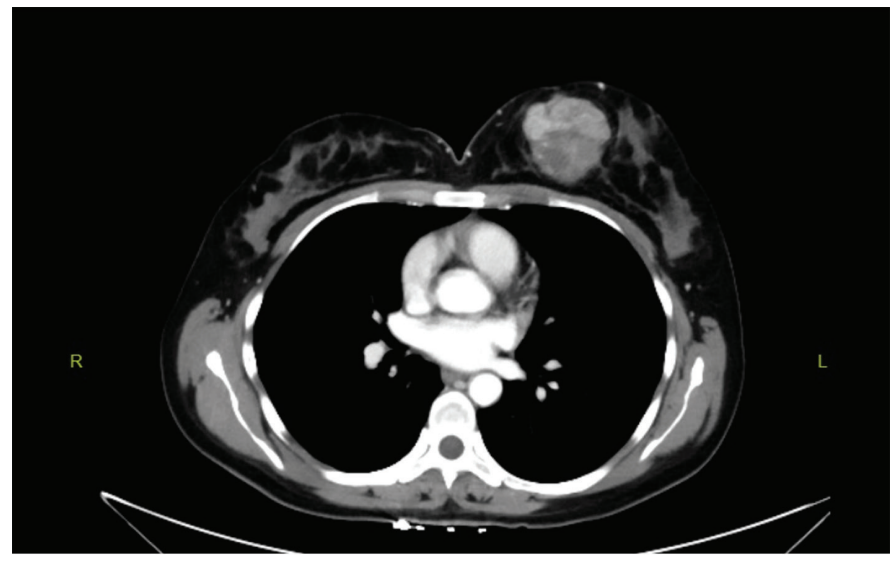

Figure 4: A giant fibroadenoma image on thorax tomography taken due to respiratory distress 
which was detected during USG. Sometimes patients can be diagnosed as a result of examinations for other reasons (Figure 4).

\section{Conclusion}

There is not a consensus in the ideal treatment protocol of GFAs. Since fibroadenomas are benign breast lesions, they do not necessarily need to be surgically removed, and may spontaneously regress. One study indicates that fibroadenomas were excised only if they did not spontaneously regress after three years of follow-ups $(11,12)$. Other studies recommend surgical excision for all cases of multiple fibroadenomas; however, this may lead to undesirable surgical scars (13). Most authors agree on the surgical excision of GFAs.

We follow non-GFAs in our clinic. We invite those who are in no-doubt about their physical examination and radiological diagnosis for a check-up every six months for the first year, and then every year for three years. If there is no change in this process, we take routine follow-up. If there is a growing or suspected malignancy in the follow-up, we take routine trucut biopsy. If there is a patient request at any time; we make surgical excision.

Several authors developed algorithms for the management of fibroadenomas, which are in fact similar to breast lesion management algorithms. Greenberg et al. (1) formed an algorithm that is based on the age of initial diagnosis, where patients that were diagnosed before turning 35 will be followed up every 6 months and should undergo surgical intervention after they turn 35 if the fibroadenoma does not spontaneously regress. For patients over 35 , the mass should be examined every 6-12 months and should be excised if it is growing or not regressing. Carty et al. (2) evaluate three separate factors (examination findings, cytology, and radiological images) for the definitive diagnosis of fibroadenoma. They indicate regular follow-ups are sufficient for most cases, the mass can be followed up for 5 years, and treatment can be planned according to the prognosis.

We recommend surgical excision in giant fibroadenomas. It compresses or replaces normal breast tissue. If there is a suspicion of malignancy in the follow-up of all fibroadenomas, a tru-cut biopsy should be performed. However; we definitely recommend biopsy before surgery regardless of malignancy suspicion in giant fibroadenomas.

\section{Ethics}

Ethics Committee Approval: Ethics committee approval was received from University of Health Sciences, Elazığ Fethi Sekin State Hospital (no: 13281952-702.99, date: 01.09.2020).
Informed Consent: Before surgery, patients signed an informed consent form for the surgical procedure and subsequent treatment, and the necessary permission was obtained to use their data in our analyses.

Peer-review: Externally peer-reviewed.

\section{Authorship Contributions}

Surgical and Medical Practices: B.H.K., N.K., Concept: B.H.K., N.K., P.G.B., Ö.A.S., Design: B.H.K., N.K., P.G.B., Ö.A.S., Data Collection or Processing: P.G.B., Ö.A.S., B.H.K., Analysis or Interpretation: B.H.K., N.K., P.G.B., Ö.A.S., Literature Search: B.H.K., N.K., P.G.B., Ö.A.S., Writing: B.H.K., N.K., P.G.B., Ö.A.S.

Conflict of Interest: No conflict of interest was declared by the authors.

Financial Disclosure: The authors declared that this study has received no financial support.

\section{References}

1. Greenberg R, Skornick Y, Kaplan O. Management of breast fibroadenomas. J Gen Intern Med. 1998;13:640-645.

2. Carty NJ, Carter C, Rubin C, et al. Management of fibroadenoma of the breast. Ann R Coll Surg Engl. 1995;77:127-130.

3. Hubbard JL, Cagle K, Davis JW, et al. Criteria for excision of suspected fibroadenomas of the breast. Am J Surg. 2015;209:297-301.

4. Hille-Betz U, Klapdor R, Henseler $\mathrm{H}$, et al. Treatment of Giant Fibroadenoma in Young Women: Results after Tumor Excision without Reconstructive Surgery. Geburtshilfe Frauenheilkd. 2015;75:929-934.

5. Bayrak IK, Özmen Z, Elmalı M, et al. Giant Juvenile Fibroadenoma: Report Of Two Cases With Ultrasonography And Magnetic Resonance Imaging Findings. J Breast Health. 2008;4:43-45.

6. Sosin M, Pulcrano M, Feldman ED, et al. Giant juvenile fibroadenoma: a systematic review with diagnostic and treatment recommendations. Gland Surg. 2015;4:312-321.

7. Cosmacini $\mathrm{P}$, Zurrida $\mathrm{S}$, Veronesi $\mathrm{P}$, et al. Phyllodes tumor of the breast: mammographic experience in 99 cases. Eur J Radiol. 1992;15:11-14.

8. Buchberger W, Strasser K, Helm K, et al. Phyllodes tumor: findings on mammography, sonography and aspiration cytology in 10 cases. AJR Am J Roentgenol. 1991;157:715-719.

9. Erözgen F, Kocakuşak A, Kızılkaya C, et al. Treatment Approaches to Recurrent Breast Phyllodes Tumors. Med Bull Haseki. 2012;50:43-47.

10. Karaveli FŞ. Fibroepitelyal Lezyonla. Karaveli FŞ, Kapucuoğlu N, çeviri editörleri. Meme Biyopsilerinin Yorumu. Nobel Tıp Kitabevi, 2014; p. 171182.

11. Cant PJ, Madden MV, Close PM, et al. Case for conservative management of selected fibroadenoma of the breast. Br J Surg. 1987;74:857-859.

12. Cant PJ, Madden MV, Coleman MG, et al. Nonoperative management of breast mass diagnosed as fibroadenoma. Br J Surg. 1995;82:792-794.

13. Williamson ME, Lyons K, Hyghes LE. Multiple fibroadenoma of the breast a problem of uncertain incidence and management. Ann R Coll Surg Engl. 1993;75:161-163. 